\title{
Additive technologies in the management of patients with extensive lower limb bone defects
}

\author{
V.P. Voloshin ${ }^{1}$, A.G. Galkin ${ }^{1}$, S.A. Oshkukov' ${ }^{1}$ A.S. Sankaranarayanan ${ }^{2}$, E.V. Stepanov ${ }^{1}$, A.A. Afanasev ${ }^{1}$ \\ ${ }^{1}$ Moscow Regional Research and Clinical Institute, Moscow, Russian Federation \\ ${ }^{2}$ Shchelkovo Regional Hospital, Moscow Region, Shchelkovo, Russian Federation
}

\begin{abstract}
Introduction Implant instability with the formation of bone defects is one of the complications after primary osteosynthesis and joint arthroplasties. Augments and reinforcing constructs made of titanium with a porous coating have been used for bone defect management in addition to osteoplastic materials. Additive technologies in traumatology and orthopedics for extensive defects in bones and joints have been applied when it is impossible to use standard designs. The purpose of the study was to evaluate shortterm results and perspectives of using additive technologies for bone defects after failed joint arthroplasties and osteosynthesis. Materials and methods In 2018 to November 2019, seven patients with lower extremity bone defects underwent treatment at the Department of Traumatology and Orthopedics of the Moscow Regional Research and Clinical Institute with custom-made implants fabricated with additive technologies. The operations were carefully planned using CT scans, 3D modeling, and implant printing. Particular attention was paid to clean the implant from residual metal powder. Patients were distributed depending on the type of defect and the operation performed (arthroplasty, revision arthroplasty). Results The short-term results of using customized implants were analyzed in this study. The average Harris hip score before surgery was 37.8 points, and after the surgery it was 80.2 points. Pain after surgery in all patients was also evaluated by Harris scale and was 37.1 points; the functionality of patients after surgery was 38.4 points. The custom-made designs have a number of distinguishing advantages against the standard ones. A customized anatomical design provides easier fixation; ergonomic design allows implant retention without removing metal fixators if exist; there is less soft tissue injury during surgery (allinside principle); and convenient bone grafting around the implant. Conclusions The use of additive technologies for bone defects improves the functional results and life quality of the patient. At the moment, practical application of $3 \mathrm{D}$ designs has a number of limitations in financial and legal support in practical health care. Further implementation of additive technologies in traumatology and orthopedics will be supported by the grant from the President of the Russian Federation.

Keywords: additive technologies, custom-made implant, defects of bones and joints, joint arthroplasty, grant of the President of the Russian Federation
\end{abstract}

\section{INTRODUCTION}

Despite current advances in reconstructive traumatology and orthopedics, the issue of managing extensive bone defects remains unresolved [1]. The use of bone-substituting materials (auto- and allografts) enhances the local regenerative potential due to their osteoinductive and osteoconductive properties. To fill in limited bone defects, augments with a porous coating, reinforcing constructs, support rings and their combinations have been used $[2,3,4]$.

In combined defects of bones and joints, when it is impossible to use the available standard arsenal, customized constructs have been implanted $[5,6]$.

The personalized approach to the patient has been gaining more and more popularity in medicine. Three- dimentional printing (3D printing) has been adapted to a wide range of surgical specialties. There have been around 370 publications on the application of 3D printing in all surgical fields according to PubMed database from 2011 to November 2019. There has been an exponential increase in research on the surgical application of $3 \mathrm{D}$ printing since 2014, with the greatest growth in maxillofacial surgery, vascular surgery, otorhinolaryngology, ophthalmology, cardiac surgery, thoracic surgery, and orthopedics $[7,8,9]$.

In traumatology, orthopedics and reconstructive surgery, 3D printing has been used to create customized exoprostheses, orthoses, training models, surgical templates for osteotomies or resections, highprecision three-dimensional models for preoperative planning, and personalized metal structures. With the help of 3D printers, customized implants are created from titanium, a bone-substituting material that enables to replace bone defects of any shape, complexity and size [10].

In Russia, the first operation using additive technologies was performed in 2015 [11]. The creation and implementation of additive technologies is possible only with an integrated approach, involving specialists in IT technologies, production sphere, engineering, and surgeons but with sufficient funding from both medical institutions and industrial enterprises [12].

The purpose of the study was to evaluate shortterm results and perspectives of using additive technologies for bone defect management after failed joint arthroplasties and osteosynthesis. 


\section{MATERIAL AND METHODS}

Starting from 2018 to November 2019, seven patients with lower extremity bone defects underwent treatment at the Department of Traumatology and Orthopedics of the Moscow Regional Research and Clinical Institute with custom-made implants fabricated with additive technologies. There were six males and one female, aged 25 to 72 years. The average follow-up was nine months. This study was approved by the local ethics board; patients signed voluntary informed consent to participate in the study. The study was conducted in accordance with the principles of the Declaration of Helsinki in its latest edition, adopted at the 64th General Assembly of the World Medical Association (WMA), Fortaleza, Brazil, October 2013.

The treated by us patients had defects of the acetabulum. Among them, patients with post-traumatic coxarthrosis were six cases, and one case was a patient that underwent total arthroplasty, revision arthroplasty for periprosthetic infection and placement of a hip joint spacer (Table 1) [13].

Table 1

Defect types in the patients treated

\begin{tabular}{|c|c|}
\hline Paprosky classification type & Number of patients \\
\hline II a & 1 \\
\hline III a & 3 \\
\hline III b & 3 \\
\hline
\end{tabular}

The complex of diagnostic procedures included radiographic and tomographic examination, general blood test for determination of the inflammatory reaction.

Based on the results of computed tomography in the 3-matic program, the bone defect was assessed with the subsequent creation of a three-dimensional digital model (Fig. 1).

The digital design has mutually equal spatial angles, which are located in the bone mass of the pubic, ischial and iliac bones. The customized implant was printed from titanium powder on a Trumpf TruPrint 1000 3D printer.

Customized implant The design has a number of advantages that distinguish it from the existing ones. They are strong and anatomical shape that ensures easy attachment and fixation; the ergonomic design allows it to be used without removing the metal fixators; low invasiveness according to the allinside principle; convenient bone grafting around the construct.

The design of the customized acetabular component provides for the principles of rational attachment. The acetabulum is formed by synostosis of three bones: iliac, pubic, ischial. The fastening provides for fixation with at least one screw with angular stability in each of the bones. Thereby, the axes of these screws intersect in the center of rotation of the hip joint at mutually equal angles (Fig. 2).
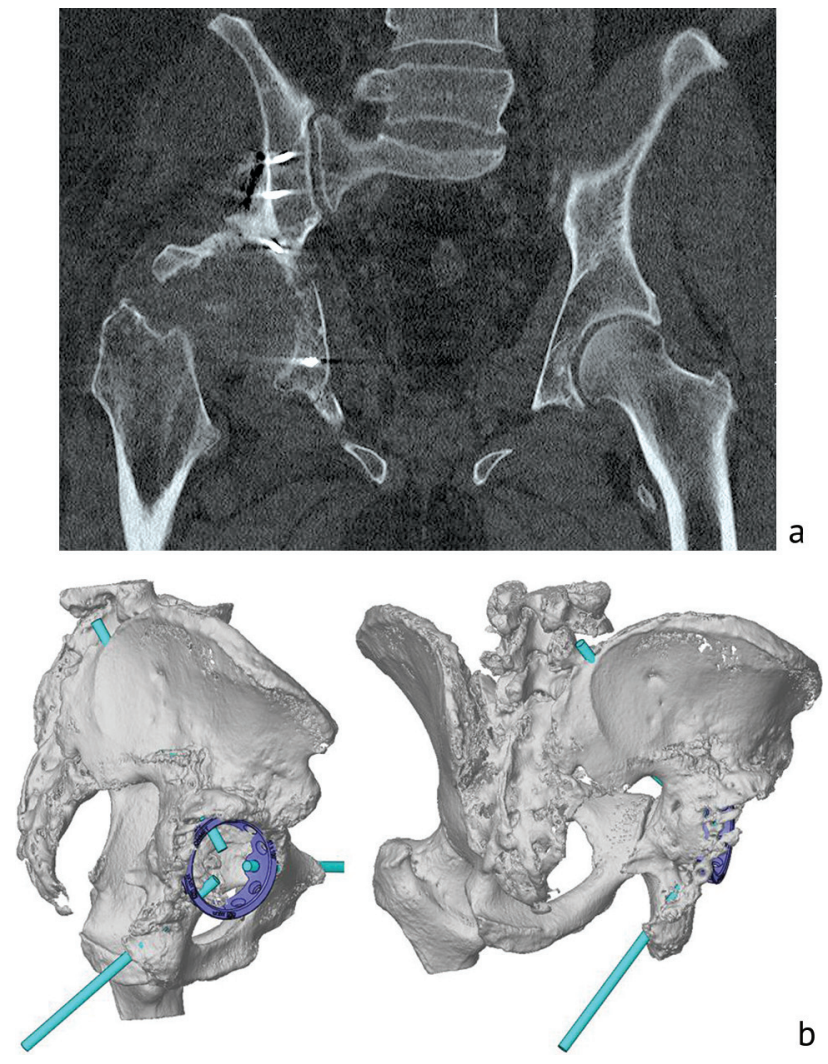

Fig. $1 \boldsymbol{a}$ computed tomography for assessing the defect of the acetabulum of the right hip joint; $\boldsymbol{b}$ three-dimensional model of a customized implant for filling the defect in the acetabulum
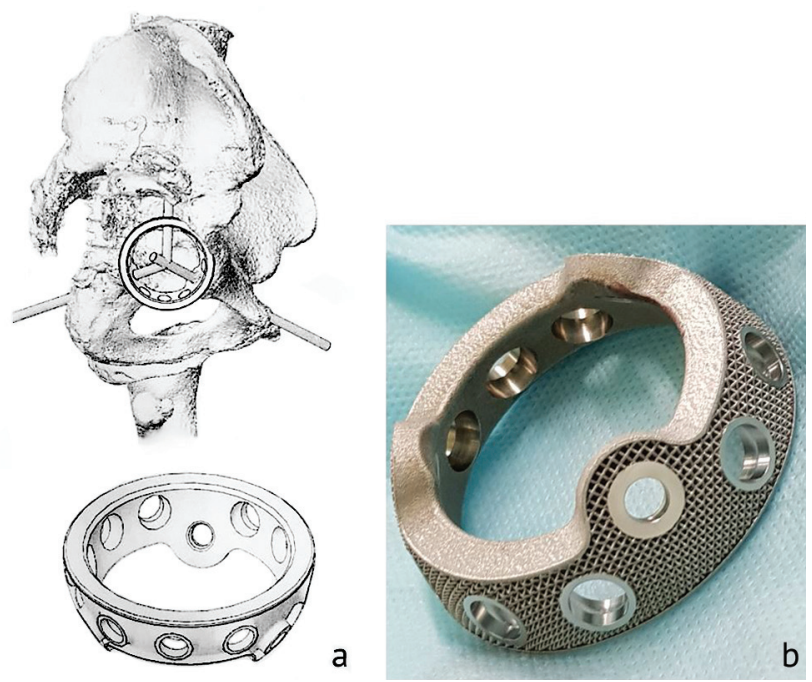

Fig. 2 Preoperative planning (a) and a customized implant (b)

The methods of surgical treatment used in this study were primary total arthroplasty ( 6 cases) and revision arthroplasty (one case) of the hip joint with the installation of a personalized reinforcing ring and bone grafting (Fig. 3).

Surgical technique The stages of the operation were as follows: posterolateral approach to the hip joint, treatment of the acetabulum, implantation of a customized construct with successive fixation 
with screws into the pubic, ischial and ilium bones, bone grafting of the acetabular defect and placement of a cemented polyethylene cup,
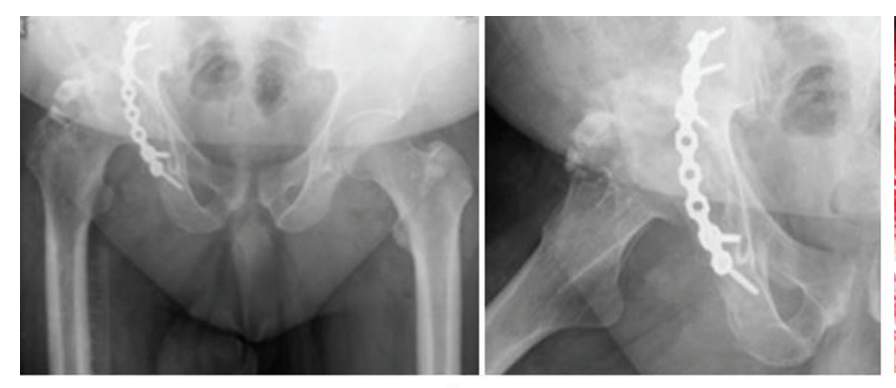

a
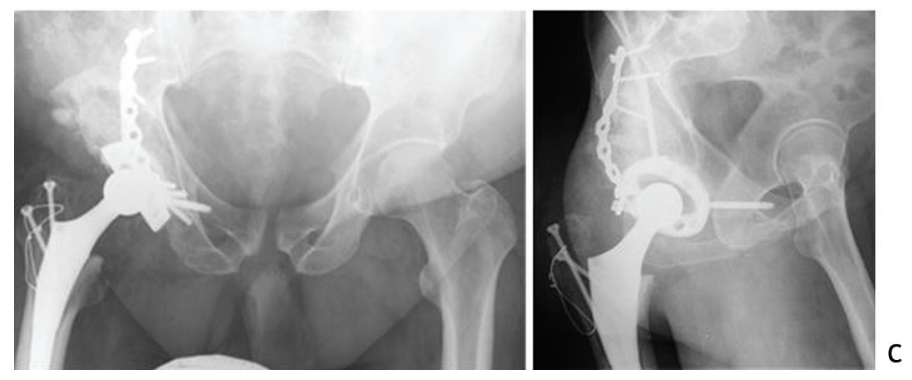

installation of the femoral component and head with its subsequent reduction. Layer-by-layer wound closure.
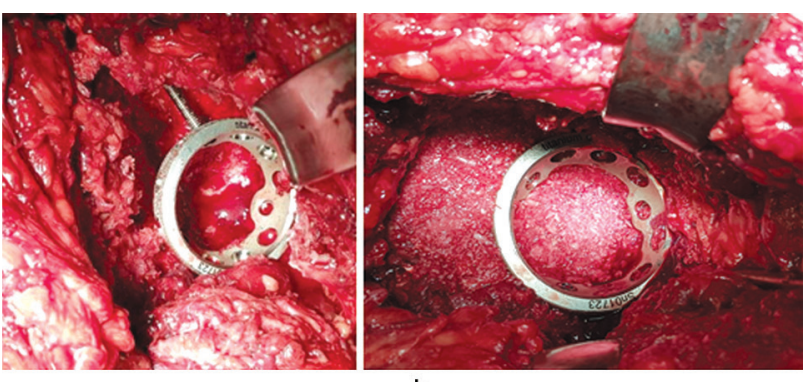

b

Fig. $3 \boldsymbol{a}$ radiographs of the hip joints of patient P., born in 1962, diagnosed with post-traumatic coxarthrosis of the right hip joint, condition after osteosynthesis of the posterior edge of the acetabulum and presence of aseptic necrosis of the head of the right femur. Acetabular defect; $\boldsymbol{b}$ installation of a customized implant and filling of the defect with bone chips (autoplasty); c control radiographs after primary arthroplasty of the right hip joint

\section{RESULTS}

Weight-bearing of the lower limb was achieved in all the cases. Early postoperative dislocation of the hip implant happened in one case. The dislocation was corrected by open reduction with the change of the femoral component and a change in spatial orientation. The complication was due to the weakness of the muscular system in the patient after repeated surgical interventions. Instability was not revealed in the follow-up dynamic radiographs.

The use of additive technologies for bone tissue defects enables compensate for the lack of bone tissue and, accordingly, to improve the results of revision interventions (Table 2).

The mean total HH score in seven patients before surgery was 37.8 points, and 80.2 points after surgery. Pain after surgery in all patients was also assessed in points on the Harris scale and amounted to 37.1 points.
Functional abilities of patients before surgery were $10.8(8-15)$ points and 38.4 points after surgery.

Drilling of canals for screws is performed from the inside of the joint thus the invasiveness of the operation is decreased, since there is no need to separate the soft tissues to attach standard flanges. The installation technology itself provides for the minimum displacement of the center of rotation of the joint implant thus contributing to a longer resource of the hinge and reduction in postoperative complications.

Bone auto- or alloplasty of the defect is used intraoperatively which procedure is convenient due to the design features, a small area and volume of an individual implant.

Radiographic osseointegration of the implant was $100 \%$, evaluated using the criteria according to Moore et al. [14].

Table 2

Clinical evaluation of arthroplasty results with Harris hip score

\begin{tabular}{|l|c|c|c|}
\hline \multicolumn{1}{|c|}{ Group $(\mathrm{n}=7)$} & Mean of total points & Pain & Function \\
\hline Before operation & $37.8(18-45)$ & $17.1(10-20)$ & $10.8(8-15)$ \\
\hline After operation & $80.2(64-92)$ & $37.1(30-40)$ & $38.4(24-44)$ \\
\hline
\end{tabular}

\section{DISCUSSION}

Modern constructions used to replace bone defects of the extremities do not always allow low-trauma, correctly oriention and stable implant placement. The use of additive technologies has a number of limitations, including funding and legal support in practical healthcare. The use of customized designs will increase with the improvement of production technologies. A distinctive feature of 3D-implants is the possibility of their use in severe clinical cases, if the known methods of treatment have been not effective [15].

The use of individual three-flange constructs has a number of disadvantages: traumatic approach, complexity of installation, disorientation of the 
individual component, and a high incidence of infectious complications [16, 17].

A distinctive feature of the proposed system is the introduction into preoperative planning of digital analysis of the results of computed tomography with a specially developed software for choosing the type and size of the necessary component, changing the design of the acetabular component due to screw holes with angular stability, while the longitudinal axes of the holes intersect at mutually equal angles in the center of the equatorial plane of the implant, similar to the crystal structure of diamond or silicon.

\section{CONCLUSIONS}

The use of the proposed customized construct enables to reduce the risk of postoperative complications; and namely, the risk of infectious complications by decreasing the time and invasiveness of the operation. According to the short-term results, no infectious complications were observed in the early and delayed postoperative periods.

Planning and digital modeling of a correctly oriented component does not always avoid dislocation of the implant due to weak muscles.
The use of additive technologies is promising not only for primary and revision hip arthroplasty, but also for revision knee arthroplasty and re-osteosynthesis of the bones of the lower extremities. Two patients have been planned to be treated in the framework of the grant from the President of the Russian Federation for defects of the femur and knee joint by arthrodesis of the knee joint with the installation of an individual rod with replacement of the defect with a porous sleeve and re-osteosynthesis with a combined customized metal fixator of the femur (1 case).

\section{Conflict of interest: not declared. \\ Funding source: state budget funding, grant from the President of the Russian Federation}

\section{REFERENCES}

1. Ling T.X., Li J.L., Zhou K., Xiao Q., Pei F.X., Zhou Z.K. The use of porous tantalum augments for the reconstruction of acetabular defect in primary total hip arthroplasty. J. Arthroplasty, 2018, vol. 33, no. 2, pp. 453-459. DOI: 10.1016/j.arth.2017.09.030

2. Migaud H., Common H., Girard J., Huten D., Putman S. Acetabular reconstruction using porous metallic material in complex revision total hip arthroplasty: A systematic review. Orthop. Traumatol. Surg. Res., 2019, vol. 105, no. 1S, pp. S53-S61. DOI: 10.1016/j. otsr.2018.04.030

3. Schreurs B.W., Busch V.J., Welten M.L., Verdonschot N., Slooff T.J., Gardeniers J.W. Acetabular reconstruction with impaction bone-grafting and a cemented cup in patients younger than fifty years old. J. Bone Joint Surg. Am., 2004, vol. 86, no. 11, pp. 23852392. DOI: $10.2106 / 00004623-200411000-00004$

4. Murylev V.Iu., Petrov N.V., Rukin Ia.A., Elizarov P.M., Kalashnik A.D. Revizionnoe endoprotezirovanie vertluzhnogo komponenta endoproteza tazobedrennogo sustava [Revision arthroplasty of the acetabular component of the hip implant]. Kafedra Travmatologii i Ortopedii, 2012, no. 1, pp. 20-25. (in Russian)

5. Kieser D.C., Ailabouni R., Kieser S.C.J., Wyatt M.C., Aarmour P.C., Coates M.H., Hooper G.J. The use of an Ossis custom 3D-printed tri-flanged acetabular implant for major bone loss: minimum 2-year follow-up. Hip Int., 2018, vol. 28, no. 6, pp. 668674. DOI: $10.1177 / 1120700018760817$

6. De Martino I., Strigelli V., Cacciola G., Gu A., Bostrom M.P., Sculco P.K. Survivorship and clinical outcomes of custom triflange acetabular components in revision total hip arthroplasty: a systematic review. J. Arthroplasty, 2019, vol. 34, no. 10, pp. $2511-2518$. DOI: 10.1016/j.arth.2019.05.032

7. Citak M., Kochsiek L., Gehrke T., Haasper C., Suero E.M., Mau H. Preliminary results of a 3D-printed acetabular component in the management of extensive defects. Hip Int., 2018, vol. 28, no. 3, pp. 266-271. DOI: 10.5301/hipint.5000561

8. Hoang D., Perrault D., Stevanovic M., Ghiassi A. Surgical applications of three-dimensional printing: a review of the current literature and how to get started. Ann. Transl. Med., 2016, vol. 4, no. 23, pp. 456. DOI: 10.21037/atm.2016.12.18

9. Tan X.P., Tan Y.J., Chow C.S.L., Tor S.B., Yeong W.Y. Metallic powder-bed based 3D printing of cellular scaffolds for orthopaedic implants: A state-of-the-art review on manufacturing, topological design, mechanical properties and biocompatibility. Mater. Sci. Eng. C. Mater. Biol. Appl., 2017, vol. 76, pp. 1328-1343. DOI: 10.1016/j.msec.2017.02.094

10.Kariakin N.N., Gorbatov R.O. Primenenie additivnykh tekhnologii 3D pechati v travmatologii, ortopedii i rekonstruktivnoi khirurgii [Application of additive 3D printing technologies in traumatology, orthopedics and reconstructive surgery]. Tezisy II Kongressa «Meditsina Chrezvychainykh Situatsii. Sovremennye Tekhnologii v Travmatologii i Ortopedii» [Proceedings of the $2^{\text {nd }}$ Congress "Emergency Medicine. Modern Technologies in Traumatology and Orthopedics"]. Pervyi Mosk. Gos. Med. Un-t im. I.M. Sechenova. M., 2017, pp. 25. (in Russian)

11.Tikhilov R.D., Shubniakov I.I., Kovalenko A.N., Bilyk S.S., Tsybin A.V., Denisov A.O., Dmitrevich G.D., Vopilovskii P.N. Primenenie individualnoi trekhflantsevoi konstruktsii pri revizionnom edoprotezirovanii s narusheniem tselostnosti tazovogo koltsa (klinicheskii sluchai) [The use of an individual three-flange design in revision arthroplasty with the interruption of the pelvic ring integrity (clinical observation)]. Travmatologiia i Ortopediia Rossii, 2016, vol. 22, no. 1, pp. 108-116. (in Russian) Available at: https://www.elibrary.ru/item.asp?id=25952941(accessed 19.11.2019).

12.Shastov A.L., Kononovich N.A., Gorbach E.N. Problema zameshcheniia posttravmaticheskikh defektov dlinnykh kostei v otechestvennoi travmatologo-ortopedicheskoi praktike (obzor literatury) [Management of posttraumatic long bone defects in the national orthopedic practice (literature review)]. Genij Ortopedii, 2018, vol. 24, no. 2, pp. 252-257. DOI: 10.18019/1028-44272018-24-2-252-257 
13.Tikhilov R.M., Shubniakov I.I., Denisov A.O. Klassifikatsii defektov vertluzhnoi vpadiny: daiut li oni obektivnuiu kartinu slozhnosti revizionnogo endoprotezirovaniia tazobedrennogo sustava? (kriticheskii obzor literatury i sobstvennykh nabliudenii) [Classifications of the acetabulum defects: do they provide an objective picture of the complexity of the hip revision arthroplasty? (a critical review of the literature and personal observations)]. Travmatologiia i Ortopediia Rossii, 2019, vol. 25, no. 1, pp. $122-141$. (in Russian) DOI: 10.21823/2311-2905-2019-25-1 122-141

14.Moore M.S., McAuley J.P., Young A.M., Engh C.A. Sr. Radiographic signs of osseointegration in porous-coated acetabular components. Clin. Orthop. Relat. Res., 2006, vol. 444, pp. 176-183. DOI: 10.1097/01.blo.0000201149.14078.50

15.Kovalenko A.N., Dzhavadov A.A., Shubniakov I.I., Bilyk S.S., Denisov A.O., Cherkasov M.A., Midaev A.I., Tikhilov R.M. Srednesrochnye rezultaty ispolzovaniia individualnykh konstruktsii pri revizionnom endoprotezirovanii tazobedrennogo sustava [Mid-term results of using individual structures for the hip revision arthroplasty]. Travmatologiia i Ortopediia Rossii, 2019, vol. 25, no. 3, pp. 37-46. (in Russian) DOI: 10.21823/2311-2905-2019-25-3-37-46

16.Glas P.Y., Béjui-Hugues J., Carret J.P. Arthroplastie de hanche pour séquelle de fracture de l'acétabulum [Total hip arthroplasty after treatment of acetabular fracture]. Rev. Chir. Orthop. Reparatrice Appar. Mot., 2005, vol. 91, no. 2, pp. 124-131. (in French) DOI: $10.1016 / \mathrm{s} 0035-1040(05) 84289-8$

17.Paprosky W.G., Muir J.M. Intellijoint HIP ${ }^{2}$ : a 3D mini-optical navigation tool for improving intraoperative accuracy during total hip arthroplasty. Med. Devices (Auckl), 2016, vol. 9, pp. 401-408. DOI: 10.2147/MDER.S119161

Received: 12.05 .2020

\section{Information about the authors:}

1. Victor P. Voloshin, M.D., Ph.D., Professor,

Moscow Regional Research and Clinical Institute, Moscow, Russian Federation

2. Anatolii G. Galkin, M.D.,

Moscow Regional Research and Clinical Institute, Moscow, Russian Federation

3. Sergei A. Oshkukov, M.D.,

Moscow Regional Research and Clinical Institute, Moscow, Russian Federation, Email: sergey0687@mail.ru

4. Arumugam S. Sankaranarayanan, M.D.,

Shchelkovo Regional Hospital, Moscow Region, Shchelkovo, Russian Federation

5. Evgenii V. Stepanov, M.D.,

Moscow Regional Research and Clinical Institute, Moscow, Russian Federation

6. Anton A. Afanasev, M.D.,

Moscow Regional Research and Clinical Institute, Moscow, Russian Federation 